\title{
Indigenous Peoples: From Unrighteousness to the Right to Self-Government
}

\author{
SUZANA KRALJIĆ \& ARMIN-BERNHARD STOLZ
}

\begin{abstract}
In the past, indigenous peoples were exposed to many violations of human rights. They were treated as nations without rights and civilisation. Colonial powers confiscated their land without paying any compensation. Their culture, religion, language, social and judicial systems were annulled or even destroyed. Members of indigenous peoples were victims of ethnocide/genocide and were used as cheap labour force. Today, many live on the edge of human society and deal with different problems (alcohol, drugs, crime). National efforts and trends to abolish the injustice made in the past, and efforts for the improvement of the present situation of members of indigenous peoples have brought fruit because indigenous peoples have reached a certain degree of autonomy in different countries through the right to self-determination and the right to self-government. Declaration on the Rights of Indigenous Peoples was adopted in 2007. It represents an important milestone in resolving many issues associated with indigenous peoples, even though individual countries with many indigenous peoples have not supported it.
\end{abstract}

KEYWORDS: $\bullet$ indigenous peoples $\bullet$ discrimination $\bullet$ minorities $\bullet$ right to self-determination $\bullet$ right to self-government

Correspondence AdDress: Suzana Kraljić, Ph.D., Faculty of Law, University of Maribor, Mladinska ulica 9, 2000 Maribor, Slovenia, e-mail: suzana.kraljic@uni-mb.si. Armin-Bernhard Stolz, Ph.D., Faculty of Law, Karl-Franzes University of Graz, Universitätsstrasse 15, Bauteil D/III, 8010 Graz, Austria, e-mail: armin-stolz@uni-graz.at. 
Today, we have no generally accepted definition of indigenous peoples. In addition, there is no unique opinion whether this term should be used at all. Namely, we can find the following expressions: indigenous peoples; tribal peoples; indigenous population; persons belonging to indigenous groups. Even in the Slovenian language, there is no unique fixed expression. Thus, we can find indigenous peoples, native peoples, autochthonous population, Aborigines, and others.

According to the present estimates, the number of members of different indigenous peoples is believed to be between 300 and 500 million people, which is around $6 \%$ of the total human population. We know that around 5,000 different indigenous peoples are represented in different ways. Some count only a few individuals, while others believe there are several thousands of members. Indigenous peoples live in more than 72 countries today, which means more than a third of all countries. The rights of some indigenous peoples (e.g., Indians) have been violated for centuries. This has been noted at the United Nations level (hereinafter referred to as UN), in regional organisations, ${ }^{1}$ and especially at the level of non-governmental organisations. Special attention is paid to indigenous peoples within the framework of the International Labour Organisation (hereinafter referred to as ILO), and the World Bank (hereinafter referred to as WB). Today, members of indigenous peoples are much better organised for enforcing their rights, which can be seen especially in exercising the right to selfgovernment as the realisation of the political aspect of the right to selfdetermination (Sarfaty, 2007: 468).

\section{Definition of Indigenous Peoples}

The topic and with it also the problems associated with indigenous peoples have gained importance and relevance during the last decades. Indigenous peoples have acquired a special status and position in international law, especially in the UN system (Burleson, 2007: 239). The indigenous peoples are not UN members, but they have an important status today, and their voice is increasingly respected, heard, and recognised.

Today, three well-established structures of general international law are mainly used in claims involving indigenous peoples: human rights, minority rights, and the right to self-determination. Thus, claims arising from slavery, genocide, discrimination, infant malnutrition, and pollution of water supplies are cognizable under international human rights law. The claims against state action in preventing the free exercise and enjoyment of group religion, culture, and language draw on international legal standards concerning minorities (Kingsbury, 1998: 437). Indigenous peoples often claim their right to self-determination, but this right 
includes particularly their aspiration for political (self-government and not an independent state), economic, cultural, and social sovereignty.

The trend towards forming a definition of indigenous peoples (that could be used in all cases) has also appeared. Most well-known definitions have been formed in the ILO Conventions under the auspices of the World Bank, in the UN Declaration on the Rights of Indigenous Peoples, and by the UN Special Rapporteur, José Martínez Cobo.

In 1989, ILO adopted Convention No. 169 concerning Indigenous and Tribal Peoples in Independent Countries (hereinafter referred to as ILO Convention 169) that replaced Indigenous and Tribal Populations Convention, 1957. ${ }^{2}$ ILO Convention 169 first gives a definition of indigenous peoples. In Article 1, this Convention applies to:

a) tribal peoples in independent countries whose social, cultural and economic conditions distinguish them from other sections of the national community, and whose status is regulated wholly or partially by their own customs or traditions or by special laws or regulations;

b) peoples in independent countries where they are regarded as indigenous on account of their descent from the populations which inhabited the country, or a geographical region to which the country belongs, at the time of conquest or colonisation, or the establishment of the present state boundaries, and who, irrespective of their legal status, retain some or all of their own social, economic, cultural, and political institutions.

The weakness of ILO Convention 169 is that it only represents a basis for the field of labour law, but not for the general regulations of the rights of indigenous peoples. Namely, in Article 1, Section 1, ILO Convention 169 expressly provides that the use of the term »peoples « in ILO Convention 169 shall not be construed as having any implications as regards the rights which may attach to the term under international law. However, the significance of the ILO Convention 169 must not be neglected because it provides an important starting-point for the rights of indigenous peoples, even if only in the field of labour law because this is usually the field where, in the past and even today, many abuses against indigenous peoples were committed in terms of cheap labour force. Another weakness of Convention ILO 169 is that it does not determine the means or forms of cooperation with indigenous peoples in national processes of decision-making, and that it gives no effective right to autonomy (Steiner \& Alston, 2000: 1008).

Under the auspices of the WB, a definition of indigenous peoples has been adopted for the needs of the WB policy. In this context, the term "indigenous peoples" is used in a generic sense to refer to a distinct, vulnerable, social and cultural group possessing the following characteristics in varying degrees: 
a) self-identification as members of a distinct indigenous cultural group and recognition of this identity by others;

b) collective attachment to geographically distinct habitats or ancestral territories in the project area and to the natural resources in these habitats and territories;

c) customary cultural, economic, social, or political institutions that are separate from those of the dominant society and culture, and

d) an indigenous language, often different from the official language of the country or region. ${ }^{3}$

The United Nations Declaration on the Rights of Indigenous Peoples (hereinafter referred to as DRIP) was adopted in 2007. It avoided the definition of indigenous peoples. Cultural, linguistic and religious pluralism is the fundamental reason for the omission of an official definition of indigenous peoples at the level of international law. The most common definition of indigenous peoples is one that has been made by the UN Special Rapporteur, José Martínez Cobo:

»Indigenous communities, peoples and nations are those which having a historical continuity with pre-invasion and pre-colonial societies that developed in their territories, consider themselves distinct from other sectors of the societies now prevailing in those territories, or parts of them. They form at present non-dominant sectors of societies and are determined to preserve, develop and transmit to future generations their ancestral territories, and their ethnic identity, as the basis of their continued existence as peoples, in accordance with their own cultural patterns, social institutions and legal systems.«(Rehman, 2003: 332)

The important reasons for the omission of a universal definition of indigenous peoples are surely the diversity of indigenous peoples and therefore different countries' views on their own indigenous peoples. However, some criteria have been formed. They need to be applied to each group of indigenous peoples.

\subsection{Self-Identification as Indigenous Peoples}

Self-identification as indigenous peoples is considered as a fundamental criterion (Sturgeon, 460). Today, all indigenous peoples of the world have the right to be recognised as distinct groups (Kingsbury: 441). But, such an opinion in the past, when indigenous peoples started to establish their trend also on international level, meat a negative reaction by the states. For fear of possible demands of indigenous peoples for an independent state, individual countries strongly denied even the existence of indigenous peoples in several cases. However, indigenous peoples usually have no such aspirations. They only wish to be identified as »peoples «. They also want more attention to be paid to their problems at the national and international levels. Indigenous people must be aware of being part of a group that differs from other people in a country or region. 


\subsection{Occupation of Ancestors' Land}

Indigenous peoples and their ancestors had lived in a certain territory before their state or geographic region were subject to occupation ${ }^{4}$ or colonisation. ${ }^{5}$ People came and occupied the land where indigenous peoples traditionally lived. Occupation was mainly conducted by force and without reparations (Williams, 1990: 683) because indigenous peoples withdrew from immigrant areas towards less favourable living areas, or they were subordinated or exploited for the interests of conquerors and colonisers. Their knowledge of the environment (e.g., new animals, new plants, search for drinking water) in which they lived, and close cohabitation with nature was unknown to the conquerors/colonisers (e.g., Aborigines). Namely, indigenous peoples and their economy (e.g., in Africa) were heavily agrarian (Ocran, 2005-2006: 467). In certain cases, conquerors/colonialists were strongly dependent on members of indigenous peoples. Therefore, successful cohabitation between indigenous peoples and immigrants occurred in certain areas.

In many countries, indigenous peoples were deported from their original territory. They settled down in areas with various environmental conditions. This means that access to fundamental resources, such as water and food, was taken away from them, as well as their holy lands and habits. In the first place, such deportation shattered the steady life of indigenous peoples, and also destroyed their social and legal structures and brought them to hunger, diseases, desperation, and death. Their traditional sacred places were subject to plundering and destruction (Vogel, 2007: 985). Their land remained subject to economic exploitation and pollution caused by it. Because of all this, indigenous peoples were marginalised and frequently subject to discrimination (also called »cultural genocide « (Lyon, 1991: 3)) in the countries where they lived (Weller: 44; Williams, 1990: 689). Today, for example, as a result of the European and American colonisation, in the USA, there are millions of acres of traditional tribal lands owned and controlled by non-Indians (Carpenter, Katyal \& Riley, 2009: 1060).

The problem regarding the land of indigenous people was especially expressive in Australia. Namely, in 1768, the official position of Great Britain was that the territory of Australia was unsettled. In 1808, Governor King declared that Aborigines were real owners of the land. In 1830, the position was that Aborigines lived in all parts of Australia and that there were no unsettled areas. However, the opposite position was taken by the Australian Courts of Justice. Namely, in conflicts referring to ownership of land, the Australian courts used the expression of "terra nullius" in their verdicts. By using it, the courts decided in accordance with the 1830 position:

a) such a position can also be found in 1836 when the Australian Supreme Court decided in the Rex v Murrel and Bummaree case that 
Aborigines had not made sufficient use of the land to enable them to have any legal claim to it; ${ }^{6}$

b) in the Attorney General v Brown case (1847), the Court of Justice decided that the Crown was the full owner of the new colony land by arguing that there was no other owner, ${ }^{7}$

c) in the Doe and Wilson v Terry case (1849), the Court of Justice took the position that the Australian colonies were uninhabited territories; ${ }^{8}$

d) in the Cooper v Stuart case in 1899, the Court of Justice stressed that Australia was unsettled before colonisation by Europeans. ${ }^{9}$ Thus, Australia was declared a state without inhabitants (disregarding the existence of Aboriginal people) in settled law. Thus, the doctrine of terra nullius was confirmed. Its essence lay in the position that the territory belonging to Aborigines prior to colonisation was legally unsettled (Anaya, 2004: 29; Waters, 2007: 669);

e) in 1971, the Australian Court of Justice even widened the terra nullius doctrine in the Milirrpum v Nabalco case because it decided that occupation of land was possible due to the fact that it was not colonised by people who had neither a social organisation ${ }^{10}$ nor a legal system in a European style; ${ }^{11}$

f) the widened doctrine of terra nullius came to expression also in the Coe v Commonwealth No. 1 case (1979) ${ }^{12}$ where it was argued that terra nullius represented a territory without civilised population or fixed law according to the European standards (Falk \& Martin, 2007: 33).

A decisive turning point was the Mabo v Queensland case in $1922 .{ }^{13}$ The result of this case was a reinterpretation of the common law doctrine to recognise native title: the beneficial ownership rights on the basis of historical use and occupancy, the rights alienable only to the state and subject to extinguishment by the state through conveyances or other official acts (Anaya, 2004: 198).

An important milestone in the case law concerning indigenous peoples is also the Canadian case of Delgamuukw v. British Columbia, $1997 .{ }^{14}$ In this case, the Canadian Supreme Court accepted oral history as an admissible form of legal evidence to prove Aboriginal title to land. The court stressed that the courts must not undervalue the evidence presented by Aboriginal claimants simply because that evidence does not conform precisely with the evidentiary standards. The use of oral histories as proof of historical facts must be placed on an equal footing with the types of historical evidence that courts are familiar with (Sarfaty, 2007: 452). The Canadian Supreme Court recognised in that case that the oral testimony, which consisted of traditional songs containing descriptions of the ancestral territory's metes and bounds, must be considered by the trial judge as evidence of the boundaries (Anaya \& Williams, 2004: 47-48). However, in the same case, the 
Court explained that the Aboriginal title is a constitutionally protected property right, but it is not an absolute right (Matoy, 2005: 468).

Some countries have adopted special land laws that limit ownership or possession of lands to indigenous peoples. There are blood quantum restrictions. Such a land law can be found in American Samoa where only those who are one-half Samoan blood may own property associated with the indigenous peoples' land. Also, in the Commonwealth of the Northern Mariana Islands, only those who are of one-fourth Northern Marianas descent may purchase property (Villazor, 2008: 807).

In New Zealand, an important step towards abolishing Maori land rights violations was made on 25 June 2008. On that day, the New Zealand Government and representatives of seven Maori tribes (Ngai Tuhoe, Ngati Tuwharetoa, Ngati Whakaue, Ngati Whare, Ngati Manawa, Raukawa, and the affiliate Te Arawa Iwi and Hapu) concluded an agreement binding the Government to pay reparations of around 243 million euros for the breach of the principles of the Treaty of Waitangi. ${ }^{15}$

Indigenous peoples have also been faced with the problem caused by creating international borders. Some indigenous people have been split by artificial borderlines. This has happened to the Alaska Native people who belong to the groups with members in the USA and Russia (Osburn, 1999/2000: 472). Also, the members of the Tohono O'Odham Nation and their ancestral lands were divided between the USA and Mexico via the Gadsden Purchase. ${ }^{16}$ The people of this indigenous nation were separated by an artificial line created by outside forces (Osburn, 1999/2000: 480).

The question arises whether the existence of a territory is a pre-requisite for the recognition of a certain group as indigenous? Namely, a certain territory is a fundamental condition for the existence of a state. ${ }^{17}$ Starting from a territory as a fundamental condition of the existence of a state, is it possible to conclude on the existence of a certain group of indigenous people? We can conclude that the existence of a territory can be regarded as an important and welcome characteristic, but not so essential that it could define the existence of a certain group as indigenous people (neither as a nation, nor as a minority, but it is a condition for the existence of a state). This can be substantiated by a case of nomadic tribes living in Africa. The Tuareg tribes live in the Central Sahara. Today, they inhabit the territories that were inhabited by them relatively late. Their demand, by which they establish their status of indigenous people, is based on marginalisation as nomadic peoples in the countries and territories dominated by the immobile agricultural population. ${ }^{18}$ 


\subsection{The Historical Tradition as a Criterion}

In certain territories, there are members of indigenous peoples and also other people. In the territories where immigration has existed for centuries (e.g., in the USA), it is frequently difficult to draw a line between indigenous peoples and immigrants. The historical tradition is the basic line by which we distinguish between indigenous peoples and the rest of the population living in this territory. Thus, we regard groups or nations with a relevant historical tradition in comparison with the society existing in the same territory that was either inhabited by greedy colonialists or invaded by other people such as indigenous peoples (Steiner \& Alston, 2000: 1007). Many settlers believed they had free rein to take control of many indigenous lands. The colonisers saw themselves not as persons dispossessing indigenous peoples, but as people making economic use of wasteland (Wiersma, 2005: 1066).

\subsection{Cultural, Social and Economic Diversity}

Indigenous peoples are bound by common social, cultural and economic characteristics. These distinct social, cultural and economic characteristics make indigenous peoples different from other social groups in a certain country or geographic area. This diversity is reflected in:

a) religion (e.g., totemism widespread among the American Indians);

b) way of living in tribal communities (e.g., Tuaregs are nomads; the Saami are engaged in deer breeding and hunting);

c) clothing and accessories (e.g., diversity with a strong sense of belonging to a tribe);

d) the social structure of communities (e.g., respect for elderly people);

e) providing the means of subsistence (e.g., infanticide and gerontocide in the past); ${ }^{19}$

f) external characteristics (e.g., Pygmy physique).

An interesting position regarding culture was given in the Kitok v Sweden case ${ }^{20}$ where priority was given to the group interest in continuing a certain cultural activity. Ivan Kitok criticised the Swedish Reindeer Husbandry Act by asserting that reindeer husbandry was an exclusive right of the Saami villages. Ethically seen, Kitok was a Saami who lost this status. His village even refused to allow him to regain his status. The UN Human Rights Council (hereinafter referred to as UNHRC) determined that reindeer husbandry was an essential element of the Saami culture. Kitok's right based on Article 27 of the International Covenant on Civil and Political Rights ${ }^{21}$ (hereinafter referred to as ICCPR) was not violated. Namely, UNCHR described the Swedish Act as a means of guaranteeing the living conditions and benefits for the Saami people. In this case, broad protection of the cultural identity of indigenous peoples was given (Smith, 2007: 427; Anaya, 2004: 136; Janko Spreizer, 2006: 249). Indigenous peoples argue that their 
cultural system cannot be maintained without securing their traditional land rights (Wiersma, 2005: 1071).

This position also derives from the Convention on the Rights of the Child ${ }^{22}$ (hereinafter referred to as CRC). The countries agree that the education of the child shall be directed to the preparation of the child for responsible life in a free society, in the spirit of understanding, peace, tolerance, equality of sexes, and friendship among all peoples, ethnic, national and religious groups and persons of indigenous origin (CRC Article 29). The wording of CRC Article 29 can be understood as a special appeal to the countries with indigenous peoples to start with bringing up children to enable them to provide a higher level of cohabitation in society, which is important for the abolishment of certain prejudices associated with indigenous peoples in a society.

\subsection{Language}

Members of indigenous peoples also differ from the rest of the population in using their language. It is meaningless whether their language is used as the sole language, as a mother tongue, as a usual means of communication at home or in the family, or it is mainly recommended as a general or normal language. Certain indigenous peoples have started to use the language of the occupiers or colonisers of certain areas. So, the use of their language has become less frequent over the years. For this reason, directives are aimed at indigenous language revitalisation (Anaya, 2004: 139). A great step in this direction has been made in New Zealand where the Maori language has become an officially recognised language. And as such, it is equal to English in spite of the fact that many Maori people cannot speak the Maori language today. Therefore, special attention has been paid to the Maori language and thereby also to the Maori culture in the Maori kindergartens or Cohanga where children are taught the Maori language and culture. ${ }^{23}$

Today, the Saami of Norway can also proudly present their success in using the Saami language. In its Article 110a, the Norwegian Constitution provides that the government authorities have the responsibility to create the conditions that enable the Saami people to preserve and develop their language (also their culture and way of life). The Norwegian courts are obliged to use the Saami language when taking evidence and in prosecution. The Saami language may also be used as a language of administration in the six municipalities (Kautokeino, Karasjok, Nesseby, Porsanger, Tana, and Kåfjord) with the largest concentration of the Saami people (Sarfaty, 2007: 454). In these six municipalities, the Norwegian and Saami languages are equal.

In its Article 30, CRC appeals to those countries in which persons of indigenous origin exist. An indigenous child shall not be denied the right (in the community with other members of his or her group) to enjoy his or her own culture, to profess 
and practise his or her own religion, or to use his or her own language. If we compare ICCPR Article 27 and CRC Article 30, there are the following differences between them:

a) CRC Article 30 refers to a child in the singular form, while ICCPR Article 27 refers to persons;

b) CRC Article 30 refers to persons of indigenous origin, and ICCPR Article 27 literally refers just to the persons belonging to minorities, but it is also used for indigenous peoples (Weller, 2005: 111);

c) In the case of the ICCPR Article 27 violation, an individual may send communication to the UNCHR in accordance with Article 1 of the Optional Protocol to the International Covenant on Civil and Political Rights $^{24}$ (hereinafter referred to as ICCPR Optional Protocol). In his/her communication, an individual can claim to be a victim of the violation by that State Party of any of the rights set forth in the ICCPR. The communication may be received by the UNCHR only if it concerns a State Party of the ICCPR Optional Protocol. However, CRC does not allow individual complaints (Libesman, 2007: 296).

\subsection{Living in Certain Parts of a Country or in Certain Parts of the World}

Indigenous peoples currently live in 72 countries. A certain group of indigenous peoples can be found only in a certain country (e.g., the Maori people in New Zealand), while individual groups can be found in several countries and continents (e.g., the Inuit people are found in the USA, Canada, Scandinavian countries, and Russia).

\subsection{Non-Dominant Position}

For several centuries, indigenous peoples have been subject to exploitation by other groups coming to the original land of indigenous peoples in many places. Exploitation was frequently done in a form of rude colonisation, including land expropriation (to one degree or another), and destruction of the original culture of indigenous peoples. So, the status of indigenous peoples developed from their former dominance in the original territory to their non-dominant position. They were subject to different forms of exploitation (Libesman, 2007: 985). In many cases, mutual extermination has also occurred between the members of different groups of indigenous peoples to get somebody else's land or riches (e.g., food, slaves ...). 
Distinguishing Between Indigenous Peoples and Minorities

First, the problems of indigenous peoples used to be dealt with along with the minority topic. But that is no longer the case today because it is clear that, in spite of certain similarities, the minority topic and the problems of indigenous peoples require independent handling and attention.

Despite the fact that today we have international documents on minority protection in international law, ${ }^{25}$ there is still no official or conventional definition of minorities. The most broadly accepted definition of minorities is the definition given by Capotorti in 1979, i.e.:

»A group numerically smaller to the rest of the population of the State, in a non-dominant position, whose members - being nationals of the State -possess ethnic, religious or linguistic characteristics differing from those of the rest of the population and show, if only implicitly, a sense of solidarity, directed towards preserving their culture, traditions, religion or language.« (Vitzhum, 2007: 260; Petrič, 1977: 87)

Capotorti stresses that for the existence of a minority, two objective conditions have to be met. The first condition is that there is a population differing from the rest of the population by a steady ethical, religious or language characteristic. Another condition is reflected in the fact that a numerical subordination towards the rest of the population has to exist. Where there are groups with an approximately equal number of members, ICCPR Article $27^{26}$ applies to all of them (e.g., 20:20:20:20:20). It has to be stressed that the range of a minority is important only regarding the realisation of minority rights. Each group has its rights, irrespective of the number of members, which are supposed to guarantee its existence and equality of its members. Therefore, a certain number or percentage of individuals is not important for the existence of a minority (Petrič: 92). When it is about an essentially smaller group, countries even avoid special measures of protection. This is justified by the fact that there is no reasonable proportionality between the invested effort and the benefit to be achieved by this effort. Except for the two objective conditions, there is also a subjective condition to be fulfilled. It refers to the group members' wish to protect their own characteristic. This general wish can be expressly made, or it can stem from group actions (Mc Kean: 144).

Between minorities and indigenous peoples there are differences that have been the basis of the indigenous peoples' arguments for separate regulation of the indigenous peoples' issues within the framework of international law. Minorities are characterised by the elements encompassed by all the characteristics of indigenous peoples. A common ethnic origin, religion, and language are elements in many cases in which a minority group differs from a major population in a 
country. Many minorities are more or less integrated into the country's population in the territory where they live. Minorities frequently wish to use their religion, language and culture. Many indigenous peoples have the opposite inclination. They establish their separate communities in the country where they live. Namely, in most cases, indigenous peoples look for a certain degree of political autonomy based on their separate identity. These differences are visible in the USA and Canada where Indian and Inuit people have a certain degree of autonomy, i.e., in a form of limited local self-government. The majority of Indian and Inuit people categorically refuse to be classified as Canadian or American citizens, and they emphasise their own nationality (Steiner \& Alston, 2000: 1010).

Further essential elements that make indigenous peoples different from minorities is their ancestral and pre-colonial connection to the territory, which is not true for minorities. The basic reasons for minorities to emerge are: territorial changes caused by wars, peace contracts, donations, marriages, heritage, conquests, end of state, migration of nations, free and forced migrations, the spread of religions, etc. (Krivokapić, 2004: 183). Therefore, minorities are often separated from their original country. ${ }^{27}$ Indigenous peoples are marked by a strong historical connection to the territory in which they had lived before they were exposed to colonisation or conquest.

Countries differently define the criteria on which their existing minorities are based (e.g., religious, linguistic, ethnic, racial criteria) ${ }^{28} \mathrm{We}$ can find minorities in almost all countries because there is practically no country without them. Indigenous peoples live in one-third of all countries today. This means that there are fewer indigenous peoples than minorities. And by number, indigenous peoples are less represented than minority members all over the world.

The above-mentioned ICCPR Article 27 is important for minority recognition. It is clear that this article applies to all minorities, irrespective of whether or not such a status is expressly recognised in the country where they live. For the existence of a minority, it is sufficient that both objective conditions are fulfilled, i.e., diversity based on religious, linguistic or ethnic characteristics, and that such a group is subordinated to the rest of the population in the country based on numbers. The existence of a minority needs no recognition by the state. However, the question arises whether ICCPR Article 27 also applies to indigenous peoples. UNHRC has given a positive answer which expressly confirms that Article 27 not only refers to the persons belonging to ethnic, religious or linguistic minorities, but also to indigenous peoples in Canada, Scandinavia, and New Zealand. ${ }^{29}$ Persons belonging to indigenous peoples can be understood to belong to ethnic, religious or linguistic minorities for the purpose of enjoying the rights mentioned in ICCPR Article 27 (Weller, 2005: 111). 
Denmark has represented the opposite position by asserting that the inhabitants of Greenland and Faeroe Islands fall under ICCPR Article $1,{ }^{30}$ and that they cannot be characterised as minorities under ICCPR Article 27. This means that the recognition of a group of people as indigenous peoples excludes the possibility of their benefit regarding the protection of a national minority at the same time. Nowadays, this opinion is not supported. The fact that a group of persons is entitled to a different form of protection cannot automatically justify their exclusion from another form of protection (Weller, 2005: 118).

The equality principle sometimes allows or even demands different handling due to a possible realisation of a certain form of protection. This is allowed provided that the preconditions below are fulfilled:

i) Different handling has to represent the protective measures taken due to the benefit enhancement for an individual group (e.g., the Sami reindeer husbandry in the Kitok v. Sweden case);

ii) This group must wish such handling;

iii) It has to be based on the needs of an individual group and not on its classification of race or skin colour;

iv) It must not last longer than necessary (Mc Kean, 1983: 91).

If any of the preconditions are not fulfilled, different handling is of an individual nature and therefore discriminatory. For the very reason that special provisions have been created, special protection of indigenous peoples as a non-dominant group within a community shall be guaranteed. De facto equality is strived for (Mc Kean, 1983: 143).

Members of indigenous peoples are also called a minority. And where it makes sense, they also enjoy international protection of minorities. In the countries which have ratified Convention ILO 169, their rights to territory and autonomy are more strongly protected than by international law provisions regarding minorities. In such cases, members of indigenous peoples give an advantage to using ILO Convention 169 over minority protection. Norway's Saami population is in such a position (Weller, 2005: 45).

\section{The Right to Self-Determination}

The roots of the right to self-determination stem from the concepts of nationality and democracy that started to develop in Europe after the First World War. Despite the efforts of President Woodrow Wilson, ${ }^{31}$ the right to self-determination was not included in the Pact of the League of Nations, neither was it recognised as a legal principle (Shaw, 2003: 225). An important milestone was set by the United Nations Charter (hereinafter referred to as UN Charter) that defined the right to self-determination as a foundation for the development of friendly relations between nations (Article 1, paragraph 2 relating to Article 55 of the UN Charter). 
The UN Charter is an important international soft-law document that sets out the human rights grounds. Although the UN Charter is a soft-law document, we cannot neglect its importance because many UN Charter provisions belong to customary international law. The UN Charter has drawn up a »catalogue of minimum human rights « that must be guaranteed to all people. Therefore, the right to self-determination is called a »third generation right $«$, and it is declared as a collective right. The right to self-determination was also proclaimed as a possibility to resolve the problem of colonialism (Naqvi, 1996: 703). The right to self- determination is also closely associated with the concept of sovereignty. However, there is an important difference between both of them: what sovereignty means to the state is the right to self-determination to people (Wutzke, 1997/1998: 514).

Important documents on the right to self-determination refer to ICCPR and International Covenant on Economic, Social and Cultural Rights (hereinafter referred to as ICESCR) whose first articles include the same wording:

»(1) All peoples have the right of self-determination. By virtue of that right, they freely determine their political status and freely pursue their economic, social and cultural development.

(2) All peoples may, for their own ends, freely dispose of their natural wealth and resources without prejudice to any obligations arising out of international economic co-operation, based upon the principle of mutual benefit, and international law. In no case may a people be deprived of its own means of subsistence."

In 1970, the Declaration on Principles of International Law Concerning Friendly Relations and Co-operation Among States in Accordance with the UN Charter ${ }^{32}$ (hereinafter referred to as Declaration on Seven Principles) was adopted, ${ }^{33}$ giving a precise concretisation and content of the principle of equal rights and selfdetermination of nations. $^{34}$ In accordance with the Declaration on Seven Principles, all peoples have the right to self-determination. By virtue of this right, they freely determine their political status and freely pursue their economic, social and culture development. All states shall observe faithfully and strictly the provisions of the UN Charter. The right to free determination of political status of indigenous peoples manifesting itself mainly in their efforts to control their lands and natural resources, and to be involved in all the decision-making processes that affect them is set to the foreground (Anaya \&Williams, 2004: 78; Skibine, 1995: 1111).

The right to self-determination is declared as a collective right because it is not given to individuals, but only to a certain group of people or members of a certain group of people. Today, the right to self-determination represents the grounds of the human rights system. At the same time, it is also part of customary international law. Even the status of ius cogens norms is recognised for it. In spite 
of its binding nature, the position of a universal model of this right cannot be taken in any way. Understanding self-determination differs across groups (Sarfaty, 2007: 489). It varies according to the circumstances of each indigenous peoples group (they come from different continents, countries, regions; their connections to natural resources differ (wood, water, deer...); their position differs in each country....). It also varies if peoples claiming the right to self-determination are dependent or colonial peoples, or they are peoples under alien domination or foreign military occupation. Self-determination is also based on the intention of racial groups that suffer from apartheid oppression, or on the ongoing selfdetermination of the whole population of a state (Foster, 2001: 143).

We distinguish between internal and external rights to self-determination. The external right to self-determination refers to the right of a nation to freely decide (i.e., without external influence) upon its political status. The internal right to selfdetermination is a classical human right, and every person has the right and opportunity to influence execution of public affairs, thereby defining his or her political status (Bakšić Muftić, 2002: 248; Schweisfurth, 2006: 382).

In addition, members of indigenous peoples have also the right to selfdetermination. It is expressly derived from the 2007 DRIP. Its Article 3 expressly determines that indigenous peoples have the right to self-determination. Thus, the collective nature of the right to self-determination is confirmed because indigenous peoples may establish themselves collectively and not individually. By enforcing this right, indigenous peoples freely decide upon their political status, and they freely pursue their economic, social and cultural development. In exercising their right to self-determination, indigenous peoples have the right to autonomy or self-government in matters relating to their internal and local affairs, and to the ways and means for financing their autonomous functions. In addition to the above, some indigenous peoples (e.g., American Indian tribes) possess inherent rights over internal tribal affairs to make substantive laws governing their members and territory (Kunesh, 2009: 403; Strommer \& Osborne, 2005: 8).

That the right to self-determination is included in the DRIP must not be taken for granted because it has been the subject of numerous discussions. The proposed right to self-determination to be expressly defined in the DRIP has met with opposition from individual governments. Some negotiators have interpreted it as the right to secession. ${ }^{35}$ On the one hand, many governments are not ready to accept this, but on the other hand, indigenous peoples just want a certain degree of territorial autonomy in the regions that are their traditional habitation areas and where indigenous peoples represent the majority (Weller, 2005: 45). The countries that most strongly oppose the regulation of the right to self-determination are those where indigenous peoples have always been exposed to the worst violations of the fundamental human rights. These countries (USA, Australia, New Zealand, Canada ${ }^{36}$ ) thoroughly follow their policy. Therefore, they voted against the 
adoption of the DRIP. 143 countries voted in favour and 11 countries abstained. So, the DRIP was adopted on 13 September 2007. In adopting the DRIP, an important role was played by the Working Group on Indigenous Peoples, established by the UN Economic and Social Council (hereinafter referred to as WGIP) in 1982. After adopting the DRIP, WGIP was replaced by the Expert Mechanism on the Rights of Indigenous Peoples (hereinafter referred to as EMRIP). ${ }^{37}$

Historical connections may have an important role in interpretation of legal principles. If there is a balance between the principle of self-determination and territorial integrity, historical connections may allow that one of the principles prevails over the other. In the case of territorial integrity, it is required that historical connections allow the state to regain its territory irrespective of the wishes of the population living there if it has a long-term connection to this land. Additionally, it is argued that the right to self-determination refers only to indigenous peoples having a long-term connection with a territory, and that immigrants or people without such a connection may not demand the enforcement of this right (Summers, 2007: 75). Such a position also stems from the Gillot et al v. France case (2002) where UNCHR decided that the referendum on selfdetermination was limited to only those who had a strong enough connection with a territory. ${ }^{38}$ This case referred to the immigrant voting right in New Caledonia. The immigrants thought that their right to vote at a referendum was violated. Their time of living in New Caledonia was relatively short (from 10 to 20 years). In other cases, historical connections are defined by a population that has lived in a territory for several centuries. Therefore, history is the key term regarding the rights of indigenous peoples. Namely, the concept of the right to selfdetermination stems from an idea that certain groups have the rights based on their longer connection (than the rest of the population) with a territory. Notwithstanding this, the International Indian Treaty Council argued that their right to self-determination existed before the emergence of the USA and even before many countries became members of the United Nations, or before many colonial societies were established (Summers, 2007: 76). Exercising the right to self-determination necessarily means that indigenous peoples exercise their right to maintain and develop their own customary law system and self-governance (Riley, 2005: 121).

\section{$5 \quad$ Indigenous Peoples and Self-Government}

\subsection{Self-Government in Brief}

Local self-government means a special autonomous public law sphere on which all democratic societies are based. Local government allows and encourages democratic participation in governance through the existence and growth of strong state political institutions (self-governance theory) (McCusker, 2009: 1561). The 
most well-known international document that deals with local self-government is the European Charter of Local Self-Government (hereinafter referred to as ECLSG) adopted by the Council of Europe (hereinafter referred to as CE) on 15 October 1985. ${ }^{39}$ The ECLSG defines local self-government as the right and ability of local authorities within the limits of the law to regulate and manage a substantial share of public affairs under their own responsibility and in the interests of the local population (ECLSG Article 3/1). However, the ECLSG has no specific provisions for indigenous peoples.

Not every community automatically forms a local self-governing community. In order to form it, four essential elements (also associated with the right of indigenous peoples to local self-government) have to be provided. They are the following:

a) The territorial element defines the borders of the land of a selfgovernment unit. Such is the case with indigenous peoples because the rights they exercise are based on local self-government (e.g., appointment of their representatives), and they are linked only to the territory that has a self-government status (e.g., the Pimicikamak Cree Nation lives in Cross Lake, in Manitoba, Canada);

b) The functional element determines the range of tasks established and realised within a certain form of local self-government (e.g., appointment of representatives of indigenous peoples to state bodies);

c) The organisational element enables community members to perform their tasks under point b) on their own responsibility either directly or through their elected bodies;

d) The material and financial element provides own material and financial resources to the local community for carrying out the projected tasks. Pursuant to the DRIP, the state must provide funding to the local community to do that.

Based on the legal element, local self-governing communities are legal entities (for more, see Šmidovnik, 1995: 29).

\subsection{Self-Government as the Right of Indigenous Peoples}

Pursuant to the DRIP, the rights of indigenous peoples are primarily of a collective nature. The rough protection of individual rights would not be sufficient for the protection of the identity characteristics of indigenous peoples (e.g., the right to self-determination) (Steiner \& Alston, 2000: 1010). So, DRIP ensures that indigenous people enjoy fully all human rights and fundamental freedoms recognised by the UN Charter, Universal Declaration of Human Rights (hereinafter referred to as UDHR), by the International Human Rights Law (DRIP Article 1), individually and in a group. Article 2 of the DRIP provides that indigenous peoples and individuals are free and equal to all other peoples and individuals, and that they have the right to be free from any kind of discrimination, 
in the exercise of their rights, in particular that based on their indigenous origin or identity. This article guarantees the principle of equal rights, and the right to freedom from discrimination in exercising the rights either individually or in a group, especially regarding their indigenous origin and identity.

The DRIP represents only a catalogue of minimum standards that must be ensured by the states for the members of indigenous peoples. The DRIP is no limit for the states to ensure a larger range of rights to indigenous peoples by national laws or through agreements with indigenous peoples.

Article 3 provides that indigenous peoples have the right to self-determination. The generic concept of self-determination relates to ideas of democratic governance and the Enlightenment belief that legitimate government depends upon the consent of the governed (Nolan-Haley, 2007: 278). By virtue of this right, they freely determine their political status ${ }^{40}$ and freely pursue their economic, social and cultural development. This implies that the DRIP defines the right to self-determination as a collective right because it cannot be exercised by an individual, but only by a group of people. Indigenous peoples want this international law to protect their collective rights in order to survive as distinct peoples (Williams, 1990: 686). The right to self-determination has been already included in the ICCPR and ICESCR. However, there is a difference between these two documents and the DRIP because ICCPR and ICESCR define the right to self-determination as the right of all people, while the DRIP describes it as the right of indigenous peoples. Such a regulation is completely understandable because the DRIP is only meant for the regulation of a certain segment, i.e., the rights of indigenous peoples. In addition, the DRIP content is limited to ratione personae. In the USA, even additional conflicts arise because the acts, which have been adopted, bind the rights of indigenous peoples and the right to selfgovernment to the blood quantum (Villazor, 2008: 819).

Article 3 supplemented with DRIP Article 4 stresses that indigenous peoples, in exercising their right to self-determination, have the right to autonomy or selfgovernment in matters relating to their internal and local affairs, as well as ways and means for financing their autonomous function. Irrespective of the view of individual countries (e.g., Canada, USA, New Zealand), which have shown fear of eventual trends of indigenous peoples towards full autonomy (Foster, 2001: 150 and f.), internal autonomy represents an acceptable compromise. In spite of the fact that they have not supported the DRIP, even these countries recognise the indigenous peoples' right to self-government by national law. American tribes enjoy their right to self-government in the way that they enact, enforce and live by their own tribal laws (either oral or codified), which apply to all tribal members. There is also an increasing number of tribal courts in place to hear disputes between members and non-members. Tribal courts vary widely in their structure: trial courts, appellate courts, peacemaker courts, ${ }^{41}$ drug courts, domestic violence 
and child custody courts (Riley, 2007b: 836). Tribal courts can use tribal customary law, but it requires first understanding the nature of customary law, and then understanding how it is used (Rosser, 2008: 19). On the one hand, tribal customary law thus enables tribal courts to judge according to the tribal history, but on the other hand, it enables them to reinforce the very same tradition (Rosser, 2008: 20).

On the other hand, there are the countries that have supported the adoption of the DRIP. Such a case is Bolivia that expressly guarantees the indigenous peoples' right $^{42}$ to self-determination, and also the right to autonomy and local selfgovernment in its 2009 Constitution (Article 2 and Article 30, Section 1, Constitution of Bolivia). The Constitution of Venezuela recognises the existence of indigenous peoples and communities and their social, political and economic organisation (Article 119, Constitution of Venezuela). Venezuela is a decentralised Federal State, governed by the principles of territorial integrity, cooperation, solidarity, attendance and shared responsibility (Article 4, Constitution of Venezuela). In each state, the Public Policy Planning and Coordination Council shall be established, and chaired by the Governor. The Council Members shall be: mayors, state directors of various ministries, legislative representatives, elected by the State to the National Assembly, as well as the Legislative Council representatives, the municipal councils, and the organised communities, including communities of indigenous peoples if they exist (Article 166, Constitution of Venezuela).

Non-governmental organisations (hereinafter referred to as NGOs) also deal with problems and issues of indigenous peoples. The NGOs have set themselves a goal to promote the recognition of the indigenous peoples' right to self-determination. This right and the rights to autonomy and self-government should be promoted at local, national, and international levels. To reach this goal, the NGOs support the indigenous peoples' equitable participation in governmental institutions in their countries. ${ }^{43}$

It has to be stressed that in the past, indigenous peoples suffered destruction of their forms of governance, community organisation, and community cohesion through the imposition of the European forms of government such as an Indian agent, the elected chief, and the council system (in Canada) which systematically sidelined and disempowered traditional forms of leadership and governance, and destroyed traditional systems for maintaining community solidarity and cohesion (Milward: 6). Since indigenous peoples (e.g., the Maori people) are already assimilated into the majority's political, legal, cultural, economic, and social systems in many places, they must be able to decide for themselves whether they are willing to live in accordance with their »traditional« or »free« views. This has also been observed by the DRIP because in Article 5, it states that indigenous peoples must have the right to maintain and strengthen their distinct political, 
legal, economic, social and cultural institutions, while retaining their right to participate fully, if they so choose, in the political, economic, social and cultural life of the State. Even before the adoption of the DRIP, many American Indian tribes succeeded in concluding agreements with the federal government in accordance with the Tribal Self-Governance Demonstration Project (1988). Based on these agreements, the Indian tribes took over the local administration programmes. They had been previously subordinated to the federal Bureau of Indian Affairs that exercised a strong power over the Indian peoples in the past (Anaya, 2004: 108).

As mentioned above, although the traditional political structure of indigenous peoples has been destroyed in many places, we have to strive to enhance respect for their right to self-government where they live, and we have to strive to renew their traditional political structure. The first positive results can already be seen. In 2004, the Government Accountability Office found out that the tribes which had participated in self-governance or enjoyed a high degree of self-determination tended to enjoy more improvements in employment, per capita income, and in poverty reduction than the other tribes did (Keohane, 2006: 9 and f.). Furthermore, the State of Maine reserved two non-voting seats in its legislature for the Passamaquody and Penobscot Indians. Although these two tribes control a large land base in the state, this fact is not recognised by the Federal Government (Wutzke, 1997/1998: 544).

The right to self-government is restricted to the field of criminal law. Namely, indigenous peoples have also developed their own systems of criminal law. In this field, the USA has enabled indigenous peoples to enjoy a certain degree of autonomy in accordance with Federal Law and Supreme Court decisions. In exercising powers of self-government, no Indian tribe shall require excessive bail, impose excessive fines, inflict cruel and unusual punishments, and in no event impose for conviction of any one offence any penalty or punishment greater than imprisonment for a term of one year or a fine of $\$ 5,000$, or both (25 U.S.C. $\S$ $1302(7)) .{ }^{44}$ For example, banishment is traditionally imposed as a legitimate form of punishment in indigenous communities, in which the main idea is that tribes have to function together to survive. Those who threaten the existence of the group and refuse to live in harmony with others could be exiled. In contrast to the American system, for example, which authorizes the execution of murderers, many tribal communities opted, instead, for banishment as a punishment for taking another's life (Riley, 2007a: 1103). Banishment was imposed in the case of two teenage Tlingit boys. They were banished from their tribal community for armed robbery of a pizza delivery man and for assault with a deadly weapon. They were exiled to a desolate island for one year where they had to survive on their own. In this case, banishment was employed as a method of bettering according to which a tribal member can sit in isolation and contemplate the consequences of his crimes before returning to his tribal community (Riley, 2007a: 1104). In the 
Nunavut self-government system, the Nunavut courts must provide the accused persons with the benefits and protections of the law equal to those enjoyed by other Canadians (Marecic, 1999/2000: 292).

In some Native American tribes, self-government for indigenous peoples is a gender-based system of self-governance. The roles of men and women are complementary and equal. But nevertheless, they are fixed or immutable. The government of the Tonawanda Band of Seneca Indians is structured around eight clans. The clan system is matrilineally based. In this system, the Clan Mother of each clan is selected by consensus. Eight Clan Mothers appoint a man to serve as tribal chief. The Clan Mothers are vested with the authority to guide some of the Tribal Chief's actions, and they may remove him if he fails to fulfil his duties (Riley, 2007b: 844).

Today, the right to self-government especially comes to expression in Canada. In the chapter below, the right to self-government realised by the Pimicikamak Cree Nation and under the Nunavut $\mathrm{Act}^{45}$ (hereinafter referred to as NA) will be presented. Although Canada has not supported the DRIP, it is all right in Canada where the members of the Pimicikamak Cree Nation ${ }^{46}$ have realised the right under Article 4 of the DRIP. It is about the deduction of the right to selfdetermination through which their right to self-government has been made more specific. The Pimicikamak claim that their right to self-determination stems from using customary law. Therefore, it is the legitimate basis for their political autonomy (Sarfaty, 2007: 444). They have developed a unique self-government model that is based on legal mediation between their local law and the Canadian and international law. Their self-government model is based on the inherent jurisdiction that seeks to reconcile tradition with modern circumstances (Sarfaty: 470). They realise that a simple return to customary practices is insufficient for effective self-governance. A government based exclusively on customary law would ignore the outside institutions that interact with contemporary society (Sarfaty, 2007: 472). That means that the inherent right to self-governance must operate within the framework of the Canadian Constitution and that the exercise of the Aboriginal right to self-government does not mean that the First Nations are free of federal or even provincial constraints (Wutzke, 1997/1998: 531).

We can present another case of sovereignty in Canada. Namely, the NA established the Nunavut territory that was officially separated from the vast Northwest Territories in 1999. The NA allows a greater degree of de facto selfgovernment, as well as recognition as a semi-sovereign entity (Sturgeon, 2005: 464). Nunavut has three regions (Kitikmeot, Kivalliq and Qikiqtaaluk/Baffin) which are the basis for the localised administration, although they lack autonomous governments of their own. 
There are between 300 and 500 million indigenous peoples around the world today. They live in more than 70 countries on all continents. Indigenous peoples are the peoples that differ from other populations. The distinction is usually based on cultural, economic, social, religious, linguistic, visual, and political diversity. In their life, they are still strongly connected with nature and natural resources. In the past, this diversity was fatal for many indigenous peoples. They were treated as peoples without rights and civilisations. They were subjected to discrimination, exploitation, deprivation of their sacral places and land, forced assimilation...However, over the last 30 years, the interest in indigenous peoples has increased at the national and international levels. At the international level, they enjoy special protection under the United Nations, World Bank, and ILO. But their protection differs at the national level. Some countries have already adopted national legal instruments in which they expressly declare the rights of indigenous peoples (Canada, Venezuela, the USA). Indigenous peoples claim their rights today because in the past, they were especially deprived of the rights to their ancestral land and sacral places. Over the last 20 years, there has been an increased emphasis placed on the right to self-government. Some indigenous people are firmly determined to exercise their right to self-government in the political system chosen by the people belonging to a specific group of indigenous peoples. Self-government of indigenous people as a group within the sovereign state must be understood as limited self-government. Indigenous peoples do not desire their own independent state. They just make a claim for an independent local or municipal government. Indigenous peoples want to enforce their right to self-government through a dialogue with the state. They want to connect their traditional political, cultural, social, and economic systems to the state system. They are aware that only the dialogue between indigenous peoples and the state will lead to positive co-operation and good results for all of them.

\section{Notes}

1 In 1948, the Organization of American States (hereinafter referred to as OAS) General Assembly made an important step toward recognition of indigenous peoples as a special subject of international concern. The OAS reguired from the states in the inter-American system to take necessary measures to protect indigenous peoples' lives and property (Anaya \& Williams, 2004: 34).

${ }^{2}$ Up to now, ILO Convention 169 has been ratified by only 20 countries which represent less than $10 \%$ of all the countries. It has been ratified by: Argentina, Bolivia, Brasil, Columbia, Costa Rica, Dominican Republic, Denmark, Equador, Fiji, Guatemala, Honduras, Mexico, Nepal, The Netherlands, Norway, Peru, Paraguay, Spain, Venezuela.

3 World Bank Operational Directive 4.20, July 2005.

${ }_{4}^{4}$ Occupation represents an act of victory over an opponent and the takeover of part of his territory or of his entire territory. The conquest brings certain rights in the scope of 


\section{LEX LOCALIS - JOURNAL OF LOCAL SELF-GOVERNMENT S. Kraljic \& A. B. Stolz: Indigenous Peoples: From Unrighteousness to the Right to Self-

international law to the winner. Thus, the winner has the right to military occupation of the territory, while the territory itself remains in legal possession of the loser's state.

${ }^{5}$ Colonisation is the most clear expression of dependence. A colonial power has full power over a dependent territory, and it carries out all its responsibilities. In a territory under colonialisation, there is no form of local self-government (Degan, 2006: 292-293).

${ }^{6}$ Rex v Murrell and Bummaree (1836) 1 Legge, p. 72.

7 Attorney-General (NSW) v Brown (1847) 1 Legge p. 312.

8 Doe and Wilson v Terry (1849) 1 Legge, p. 508.

${ }_{9}$ Cooper v Stuart (1889) 14 App. Cas. 286.

${ }^{10}$ Indigenous peoples have always had their political and social structures. This also applies to the Native Hawaiian people who lived in a society with highly complex political and social systems before the arrival of Europeans in 1778. Separate high chiefs governed the major islands, with subordinate chiefs managing ahupua'a, self-sustaining land units. Within the ahupua'a, the people had use rights to the resources necessary to sustain life (MacKenzie, 2006: $15)$.

11 Milirrpum v Nabalco Pty Ltd (1971) 17 FLR 141.

12 Coe v Commonwealth (1979) 24 ALR 118.

13 Mabo v Queensland No. 2 (1992) HCA 23.

${ }^{14}$ Delgamuukw v. British Columbia (1997) 3 S. C. R. 1010 (Can.).

15 Internet sources: http://nz01.terabyte.co.nz/ots/DocumentLibrary\%5CCNIsummary.pdf (23. August 2008); http://www.nzherald.co.nz/section/1/story.cfm?c_id=1\&objectid=10518 293 (23. August 2008); http://www.beehive.govt.nz/speech/address+central+north+ island + iwi + collective + deed + signing (23. August 2008).

16 Known also as Venta de La Mesilla or Sale of La Mesilla. In December 1853, a territory $(76,800 \mathrm{sq} \mathrm{km})$ treaty was concluded. The territory was purchased by the USA from Mexico. At that time, James Gadsden was the American ambassador to Mexico, and thus the treaty is also known as the Gadsden Treaty or the Gadsden Purchase. The purchase included lands south of the Gila River and west of the Rio Grande River. The U.S. paid Mexico \$10 million for the territory. See more at http://avalon.law.yale.edu/19th_century/mx1853.asp (13.10.2009); http://www.state.gov/r/pa/ho/time/dwe/87721.htm (13.10.2009).

17 The fundamental conditions for the existence of a state were determined in the Convention on the Rights and Duties of States signed in Montevideo on 26 December 1933. Later on, this Convention became part of customary international law. Article 1 provides that the state as a person of international law should possess the following qualifications: (a) a permanent population; (b) a defined territory; (c) government; and (d) capacity to enter into relations with other states. Article 3 of the Convention provides the basis for the so-called declarative theory of statehood (its opposite is the constitutive theory of statehood - a state can only exist if it is recognised by other states). Article 3 expressly provides that the political existence of the state is independent of recognition by other states (see more in Degan, 2006: 224 and Shaw, 2003: 178 and f.; Türk, 2007: 86 and f.; Brownlie: 70 and f.; Kreča: 128 and f.; Hailbronner in Vitzthum: 187 and f.; Schweisfurth: p. 10 and f..). Slovenia also met the above-mentioned conditions and became an independent state in 1991. Slovenia adopted Constitution on 23 December 1991 (Geč-Korošec \& Rijavec, 1995: 486), and our country became a UN member in May 1992.

${ }_{18}$ www.peoplesoftheworld.org/text?people=Tuareg (6.10.2008).

19 Certain groups of Indians and aboriginal Eskimos (it is about indigenous peoples) committed infanticide (killing children) and gerontocide (killing elderly people). In dry regions of Australia, female infanticide was committed to reduce the number of population in times of hunger. Therefore, babies were eaten. In Tasmania, old hunters lived a nomadic life in order to be able to use seasonally available foods in different areas. Since the old and helpless people 
were too weak to follow the group, they were left behind to die. The Caribou Indians living west of Hudson Bay in Canada strongly depended on deer meat. If there were no deer during winter, hunger appeared. In order to prevent hunger among the whole group, they set up priorities. First, they fed active male adults because they provided food. They needed strength. If they were too weak for hunting, all members of the group would be left without food. Then they fed females so that they could give birth to many children. Boys were more important than girls because they were supposed to grow into hunters. Elderly people were the last group on the list. They committed suicide in times of hunger by going naked into the snow. If there were no more elderly people, they killed girls (Haralambos \& Holborn, 2005: 12).

${ }^{20}$ Communication 197/1985, UN Doc. CCPR/C/33/D/197/1985.

21 Official Journal of the SFRY-IC, No. 7/1971; Official Journal of the RS, No. 9/1992.

22 General Assembly Resolution 44/25 of 20 November 1989; Slovenia - Official Journal of the RS - IC, No. 9/1992.

23 A similar point of view regarding the Romany language revitalisation and development has been given in Slovenia. Namely, Slovenia is the first country in Europe to adopt a special act regulating the position of the Romany community. The Romany community, departing from the Slovenian constitution (comp. Article 65), is not a national minority in Slovenia. The Italian and Hungarian minorities are the only ones in our country. The Romany Community Act was adopted in 2007. It accepted the principle of the right to use one's own language and writing. In order to exercise this right, special emphasis is placed on the promotion and development of the Romany language in the Slovenian primary schools and communities where the Romany community lives. The following activities have been carried out: an optional subject called "the Romany language and culture" has been prepared and adopted; a professional standard for the Romany assistant has been prepared and adopted; intercultural cohabitation programmes have been prepared and adopted; teachers have become familiar with the Romani history, culture, etc. to improve their communication with the Romany pupils (Kraljić \& Ivanc, 2009: 448).

${ }^{24}$ General Assembly Resolution 2200A (XXI).

25 International documents dealing with minority protection were adopted within the framework of the United Nations (e.g., ICCPR Article 27), Council of Europe (e.g., Framework Convention for the Protection of National Minorities, European Charter for Regional and Minority Languages), European Union (e.g., the so-called Race Directive (Council Directive 2000/43/EC of 29 June 2000 implementing the principle of equal treatment between persons irrespective of racial or ethnic origin) as well as OSCE (e.g., Helsinki Final Act).

26 ICCPR Article 27: »In those States in which ethnic, religious or linguistic minorities exist, persons belonging to such minorities shall not be denied the right, in community with the other members of their group, to enjoy their own culture, to profess and practise their own religion, or to use their own language."

27 The separation from the original country cannot be defined as a fundamental criterion for the existence of a minority because different countries recognise minority status also to the minorities without their own country (e.g., Romanies).

28 International law and regulations give no general directives to be used as an overall definition of minorities. Based on this inconsequence, the countries have great autonomy in deciding on their own, especially according to their interest, which communities will be granted minority status in their country. Some approaches of the countries towards resolving the problem of minorities: a) countries do not recognise that there are minorities in their territory despite the opposite facts; b) countries expressly avoid recognition of minorities in their territory, but they recognise the fundamental rights of minority members in a concealed way (e.g., Bulgaria); c) countries recognise certain rights of minority members, but they provide no 


\section{LEX LOCALIS - JOURNAL OF LOCAL SELF-GOVERNMENT

definition who the minority members are; d) countries expressly specify which minorities live in their territory (e.g., Article 64 of the Constitution of the Republic of Slovenia provides that there are only the Hungarian and Italian national minorities in Slovenia); e) countries provide an abstract definition of minorities, and anybody who meets the conditions set out in the definition may consider himself or herself a member of a certain minority (Krivokapić:, 2004 219-221).

29 See Communication No. 167/1984 (Bernard Ominayak, Chief of the Lubicon Band v. Canada, views adopted on 10 May 1990 (CCPR/C/38/D/167/1984), and the abovementioned Kitok v. Sweden case.

${ }^{30}$ India made a reservation to Article 1, Section 1 of the ICCPR. It declared that the words the »right to self-determination « refer only to the people under foreign sovereignty, and these words do not apply to souvereign independent states, or a group of people or a nation being a composite part of this national souvereignty.

31 The right to self-determination was first mentioned by Lev Trotzki within the Zimmerwald Manifesto (15 September 1915) where he wrote that the right of nations to self-determination has to be an unlimited fundamental principle of international relations. Then President Woodrow Wilson picked up Trotzki's idea in his memorable Fourteen Points speech on 8 January 1918.

32 UN General Assembly Resolution 2625 (XXV), 24 October 1970.

33 Seven Principles Declaration has the nature of an authoritative interpretation of the UNC. According to the opinion of the International Court of Justice in The Hague, the Nicaragua vs. United States case (1984) was transferred to customary international law (Türk, 2007: 157).

34 Already in 1960, the UN General Assembly adopted Declaration on the Granting of Independence to Colonial Countries and Peoples (General Assembly Resolution 1514 (XV), 14 December 1960) that also determined the right to self-determination.

35 Secession is a way of establishing a new state. From the former state, a certain part of its territory is separated and it becomes a new state. The predecessor state still exists (there is no change in the legal order).

36 Although Canada voted against the adoption of the DRIP, it needs to be emphasised that in its 1982 Constitution, Canada recognised indigenous status of three groups of indigenous peoples, i.e., the Indian, Inuit and Métis peoples of Canada (Article 35, Section 2). In addition, Section 1 of the same Article of the Constitution recognised and affirmed the existing aboriginal and treaty rights of the aboriginal peoples of Canada. Under this article, Aboriginal Title was recognised (see more in Lyon, 1991: 4; Matoy, 2005; Palmer, 2007: 23; Wutzke, 1997/1998: 527).

${ }^{37}$ EMRIP was established by the Human Rights Council by means of its Resolution 6/36 on 14 December 2007.

38 Gillot et al v. France - Communication 932/2000, UN Doc. CCPR/C/75/D/932/2000.

39 Slovenia ratified it on 15 November 1996 (Official Journal of the RS - MP, No. 15/1996).

${ }^{40}$ In order to determine their own destiny by choosing their institutions and their political status, the rights of indigenous peoples are also set forth in paragraph 2 of the Resolution of the European Parliament on Action Required Internationally to Provide Effective Protection for Indigenous People (9 February 1994) (A3-0059/94); the Kari-Oca Declaration and the Indigenous Peoples (1992) determines that indigenous peoples have always had the right to decide about their own forms of government.

${ }^{41}$ The Navajo Peacemaker Court: the Navajo Nation believes that all things in the universe are interconnected. The divine and the secular are inseparable, and the activities, ceremonies, and rituals of day-to-day life are designed to secure balance in the universe. In the Navajo system, extended family networks play a critical role in achieving this sacred balance. If the potential litigans in the Navajo Nation want to avoid litigation and the adversary systen, they may take 
their case to a Peacemaker Court. The naat'aani or peacemakers are leaders selected by the community. The peacemaker process is infused with ceremony, tradition and religious significance. Proceedings are generally commenced with prayer for reconciliation. In the proceedings, everyone has the opportunity to be heard. The peacemaker's role is to talk out the problem, but not to judge. He guides the participants to the resolution (Riley, 2007a: 1094, 1095).

42 These have the status of indigenous peoples in Bolivia: Aymara, Araona, Baure, besir, Canichana, Cavineño, cayubaba, Chacobo, shaman, that Ejja, Guarani, guarasu'we, Guarayu, Itonama, Leco, machajuyaikallawaya, machineries, Maropa, Mojeno-Trinitarian MojenoIgnatian, more, Moseten, Movima, pacawara, Puquina, Quechua, Siriono Tacana, Tapiete, Toromona, uru-Chipaya, weenhayek, Yaminawa, yuki, Yuracare and Zamuco (Paragraph 1, Article 5 of the Constitution of Bolivia).

43 Paragraph 10 of the 43rd International Treaty between Non-Governmental Organisations and Indigenous Peoples. A similar provision is also in the Declaration on the Rights of the Indigenous Peoples of Sarawak, Sabah and Peninsular Malaysia in their demand No. 4. They demand freedom to determine and control the justice system in their communities in accordance with their traditions.

44 Except in the cases mentioned (25 U.S.C. \ 1302(7)), Article 1302 contains another 9 paragraphs, i.e., No Indian tribe in exercising powers of self-government shall: (1) make or enforce any law prohibiting the free exercise of religion, or abridging the freedom of speech, or of the press, or the right of the people peaceably to assemble and to petition for a redress of grievances; (2) violate the right of the people to be secure in their persons, houses, papers, and effects against unreasonable search and seizures, nor issue warrants, but upon probable cause, supported by oath or affirmation, and particularly describing the place to be searched and the person or thing to be seized; (3) subject any person for the same offence to be twice put in jeopardy; (4) compel any person in any criminal case to be a witness against himself; (5) take any private property for a public use without just compensation; (6) deny to any person in a criminal proceeding the right to a speedy and public trial, to be informed of the nature and cause of the accusation, to be confronted with the witnesses against him, to have compulsory process for obtaining witnesses in his favour, and at his own expense to have the assistance of counsel for his defence; (7) sea above; (8) deny to any person within its jurisdiction the equal protection of its laws or deprive any person of liberty or property without due process of law; (9) pass any bill of attainder or ex post facto law; or (10) deny to any person accused of an offence punishable by imprisonment the right, upon request, to a trial by jury of not fewer than six persons.

45 Nunavut Act, S.C. 1993 , c. 28.

46 Pimicikamak Cree Nation, an indigenous people living in Cross Lake, a small town in Manitoba, Canada. 


\section{References}

Anaya, J. S. (2004) Indigenous People in International Law, Second Edition, (Oxford: Oxford University Press).

Anaya J. S. \& Williams R. A. (2001) The Protection of Indigenous Peoples' Rights over Lands and Natural Resources Under the Inter-American Human Rights System, Harvard Human Rights Journal, 14, pp. 33-87.

Bakšić Muftić J. (2002) Sistem ljudskih prava (Sarajevo: Fond Otvoreno društvo BiH, Pravni centrar).

Burleson, E. (2007) Tribal, State and Federal Co-operation to achieve Good Governance, Akron Law Review, 40 (2), pp. 207-254.

Carpeneter, K. A., Katyal, S. K. \& Riley, A. R. (2009) In Defence of Property, Yale Law Journal, 118 (6), pp. 1022-1125.

Degan, V. D. (2006) Međunarodno pravo (Rijeka: Pravni fakultet Sveučilišta u Rijeci).

Falk, P. \& Martin, G. (2007) Misconstruing Indigenous Sovereignty: Maintaining the fabric of Australian law, In: Moreton-Robinson, A. (ed.), Sovereign Subjects - Indigenous Sovereignty Matter (Crows Nest: Allen\&Unwin), pp. 33-46.

Foster, C. E. (2001) Articulating Self-determination in the Draft Declaration on the Rights of Indigenous Peoples, European Journal of International Law, 12 (1), pp. 141-157.

Haralambos, M. \& Holborn, M. (2005) Sociologija, Teme in pogledi (Ljubljana: DZS).

Geč-Korošec, M. \& Rijavec, V. (1995) Slovenia - Postindependence Changes in Family- Law Regulation, University of Louisville Journal of Family Law, 33 (2), pp. 485-493.

Janko Spreizer, A., (2006) Avtohtonost v slovenskem narod(nost)nem vprašanju in koncept staroselstva: nastavki za analizo ideologij primata, Rasprave in gradivo: revija za narodnostna uprašanja, 50/51, pp. 236-271.

Keohane, J. R. (2006) The Rise of Tribal Self-determination and Economic Development, Human Rights, 33 (2), pp. 9-12.

Kingsbury, B. (1998) 'Indigenous Peoples' in International Law: A Constructivist Approach to the Asian Controversy, American Journal of International Law 92 (3), pp. 414-457.

Kraljić, S. \& Ivanc, T. (2009) Discrimination of Romani Children in Slovenia - Positive or negative?, In: Atkin, B. (ed.) The international survey of family law (Bristol: Family Law, Jordan Publishing).

Kreča, M. (2007) Međunarodno javno pravo (Beograd: Službeni glasnik).

Krivokapić, B. (2004) Zaštita manjina u međunarodnom i uporednom pravu (Beograd: Minstarstvo za ljudska in manjinska prava SCG).

Kunesh, P. H. (2009) Tribal Self-Determination in the Age of Scarcity, South Dakota Law Review, 54 (3), pp. 398-419.

Libesman, T. (2007) Can International Law Imagine the World of Indigenous Children, International Journal of Children's Rights, 15 (2), pp. 283-309.

Lyon, N. (1991) Aboriginal Peoples and Constitutional Reform in the 90's (Kingston, Ont.: Institute of Intergovernmental Relations).

MacKenzie Kapilialoha, M. (2006) Ever Loyal to the Land: The Story of the Native Hawaiian People, Human Rights, 33 (2), pp. 15-17.

Marecic, C. J. (1999/2000) Nunavut Territory: Aboriginal Governing in the Canadian Regime of Governance, American Indian Law Review, 24 (2), pp. 275-295).

Matoy, C. K. (2005) Does Constitutional Change Matter? Canada's Recognition of Aboriginal Title, The Arizona Journal of International and Comparative Law Online, 22 (3), pp. 449-503.

Mc Cusker, C. (2009) The Federalism Challenges of Impact litigation by State and Local Government Actors, Yale Law Journal, 118 (7), pp. 1557-1570.

Mc Kean, W. (1983) Equality and Discrimination under International Law (Oxford: Claredon Press). 
Milward, D. (2009) Restless Spirits in the Land: Finding a Place in Canadian Law for Aboriginal Civil Disobedience, International Journal on Minority and Group Rights, 16 (1), pp. 1 29.

Naqvi, F. H. (1996) People's Rights or Victim's Rights: Re-examining the Conceptualization of Indigenous Rights in International Law, Indiana Law Journal, 71 (3), pp. 673-728.

Nolan-Haley, J. (2007) Self-determination in International Mediation: Some Preliminary Reflections, Cardozo Journal of Dispute Resolution, 7 (2), p. 701.

Ocran, M. (2005-2006) The Clash of Legal Cultures: The Treatment of Indigenous Law in Colonial and Post-Colonial Africa, Akron Law Review, 39 (2), pp. 465-482.

Osburn, R. (1999/2000) Problems and Solutions regarding Indigenous Peoples split by International borders, American Indian Law Review, 24 (2), pp. 471-485.

Palmer, M. S. R. (2007) Constitutional Realism about Constitutional Protection: Indigenous Rights under a Judicialized and a Politicized Constitution, Dalhousie Law Journal, 1 (1), p. 141.

Petrič, E. (1977) Mednarodnopravno varstvo narodnih manjšin (Maribor: Založba obzorja).

Rehman, J. (2003) International Human Rights Law - A Practical Approach (Dorchester: Pearson Education Limited).

Riley, A. R. (2007) Good (Native) Governance, Columbia Law Review, 107 (5), pp. 1049-1125.

Riley, A. R., (2007) (Tribal) Sovereignty and Liberalism, California Law Review, 95 (3), pp. 799 848.

Riley, A. R. (2005) 'Straight Stealing': Towards an Indigenous System of Cultural Property Protection, Washington Law Review, 80 (1), pp. 69-164.

Rosser, E. (2008) Customary Law: The Way Things were, codified, Tribal Law Journal, 8, pp. 18-33.

Sarfaty, G. A. (2007) International Norm Diffusion in the Pimicikamak Cree Nation: A Model of Legal Mediation, Harvard International Law Journal, 48 (2), pp. 441-482.

Schweisfurth, T. (2006) Völkerrecht (Tübingen: Mohr Siebeck).

Shaw, M. N. (2003) International Law, 5th edition (Cambridge: Cambridge University Press).

Skibine, A. T. (1995) Reconciling Federal and State Power Inside Indian Reservations with the Right of Tribal Self-Government and Process of Self-Determination, Utab Law Review, 57 (4), pp. 1105-1157.

Smith, R. K. K. (2007) International Human Rights, Texts and Materials (New York: RoudledgeCavendish).

Steiner H. J. \& Alston, P. (2000) International Human Rights in Context, Second Edition (Oxford: Oxford University Press).

Strommer, G. D. \& Osborne, S. D. (2005) »Indian Country« and the Nature and Scope of Tribal Self-Government in Alaska, Alaska Law Review, 22 (1), pp. 1-35.

Sturgeon, L. (2005) Constructive Sovereignty of Indigenous Peoples, Chinese Journal of International Law, 6 (2), pp. 455-466.

Summers, J. (2007) Peoples and International Law, How Nationalism and Self-Determination Shape a Contemporary Law of Nations (Leiden-Boston: Martinus Nijhoff Publishers).

Šmidovnik, J. (1995) Lokalna samouprava (Ljubljana: Cankarjeva založba).

Türk, D. (2007) Temelji mednarodnega prava (Ljubljana: GV Založba).

Villazor, R. C. (2008) Blood Quantum Land Laws and the Race Versus Political Identity Dilemma, California Law Review, 96 (3), pp. 801-837.

Vitzthum, W. \& Bothe, M. (2007) Völkerrecht (Berlin: De Gruyter Recht).

Vogel, H. J. (2007) Healing the Trauma of America's Past: Restorative Justice, Honest Patriotism and the Legacy of Ethnic Cleansing, Buffalo Law Review, 55 (3), pp. 981-1046.

Waters, M. A. (2007) Creeping Monism: The Judical Trend Toward Interpretative Incorporation of Human Rights Treaties, Columbia Law Review, 107 (3), pp. 628-705. 
LEX LOCALIS - Journal OF LOCAL SELF-GOVERNMENT

Weller, M. (ed.) (2005) The Rights of Minorities, A Commentary on the European Framework Convention for the Protection of National Minorities (Oxford: Oxford University Press).

Wiersma, L. L. (2005) Indigenous Lands As Cultural Property: A New Approach to Indigenous Land Claims, Duke Law Journal, 54 (4), pp. 1061-1088.

Williams, R. A. (1994) Linking Arms Together: Multicultural Constitualism in a North American Indigenous Vision of Law and Peace, California Law Review, 82 (4), pp. 981-1049.

Williams, R. A., (1990) Encounters on the Frontiers of International Human Rights Law: Redefining the Terms of Indigenous Peoples Survival in the World, Duke Law Journal, 1990 (4), pp. 660-704.

Wutzke, J. (1997/1998) Dependent Independence: Application of the Nunavut Model to Native Hawaiian Sovereignty and Self-Determination Claims, American Indian Law Review, 22 (2), pp. 509-565. 